\title{
Hva med pasientplikter?
}

\author{
Pasientrettighetsloven sier lite om pasientplikter. Det er f.eks. ikke pålagt å gi sannferdige fremstillinger \\ til helsevesenet. Oppdiktede sykehistorier kan føre til store utbetalinger fra det offentlige og fra forsikrings- \\ selskaper. Men dersom svindelen avdekkes, kan det få store konsekvenser for pasienten. Kunne innføring \\ av pasientplikter ha bedret situasjonen?
}

Behandling er samarbeid mellom pasient og behandler(e). Det krever god informasjon og tillit begge veier. Pasientrettighetsloven (1) skal blant annet bidra til å fremme tillitsforholdet mellom pasient og helsetjeneste og ivareta respekten for den enkelte pasients menneskeverd.

\section{Immunitet mot uetterrettelighet?} Pasientrettighetsloven klargjør pasientens rettigheter i dagens behandlingsapparat, men den sier ingenting om pasientplikter utover det nye kapittel 4A som pålegger enkelte personer å motta behandling de motsetter seg. Loven pålegger f.eks. ikke pasienter å være sannferdige i sine fremstillinger. Når en person oppnår pasientstatus, kan det se ut som at en uskreven immunitet mot uetterrettelighet trer i kraft. Man kan ikke trekke pasientens angivelse av smerter og funksjonsnedsettelse i tvil. Man skal ikke mistro et sykt menneske. Helsevesenets oppgave blir å finne ut av hva som er årsaken til de angitte plager og igangsette adekvat behandling.

Men iblant er symptompresentasjon og kliniske funn så fjernt fra kjente sykdomstilstander at det synes klart at noe ikke stemmer. Men det kan man ikke si til en pasient. Vi må ta deres plager på alvor og prøve å hjelpe med en eller annen form for behandling. Og vil pasienten bli sykmeldt, oppfylles som regel også det ønsket. Behandlerrollen kan da lett bli omgjort til en passiv medhjelperrolle i en oppholdende, men kanskje hensiktsløs behandling. Dette kan bli ressurskrevende for helsevesenet og dyrt for samfunnet, noe man vil erfare som spesialist innen muskelog skjelettlidelser der henvisning av slike pasienter forekommer ikke helt sjelden.

\section{Somatisering eller simulering?}

Med somatisering forstår man presentasjon av fysiske plager, i første rekke langvarige smerter, uten at det er mulig å påvise sikre forstyrrede fysiologiske prosesser eller avvikende anatomiske forhold som på en rasjonell måte kan forklare tilstedeværelsen av smertesymptomene (2). Ved simulering «skapes» symptomer og funksjonssvikt, ofte kopiert ut fra kjente medisinske tilstander, men der disse ikke lar seg gjenfinne som objektive funn ved kliniske, bildediagnostiske eller hematologiske undersøkelser. Derimot kan det ved simulering, men ikke ved somatisering, foreligge positive svar på kliniske avledningstester og irrelevante kliniske tester ved angitte plager i muskel- og skjelettsystemet $(3,4)$. Slike tilleggsundersøkelser kan langt på vei skille bevisst aggravering og simulering fra somatoforme tilstander.

\section{Er pasientuetterrettelighet et problem?}

Pasientuetterrettelighet er ikke et problem for det store antall pasienter som søker hjelp for plager og funksjonssvikt. Men med stadig nye forsikringsordninger som gir mulighet for utbetaling til «alle» i forbindelse med skader påført $i$ arbeid og fritid, må man også påregne at forsøk på forsikringssvindel pga. «helsetap» kan forekomme.

I en tre års oppfølgingsstudie av yrkesskadede fant man at helseplager var mest uttalt etter uspesifikke bløtdelsskader (5). Flertallet av skadene ble bedømt som beskjedne, hvorav trygdeytelser ble gitt ved over halvparten. Den manglende - og til dels inverse sammenheng mellom skaden og dens kliniske konsekvenser, syntes forfatterne det var vanskelig å forklare.

Legens portvaktfunksjon på vegne av fellesskapet er krevende. Å mistro en pasient og ikke tilby behandling og trygdeytelser er svært ubehagelig og noe man vil unngå i det lengste. Men har man først startet en behandling, kanskje på et noe tvilsomt klinisk grunnlag, og behandlingen ikke virker, da må man følge opp med ny behandling, og stadig ny behandling og stadig ny sykmelding, så lenge pasienten vil ha behandling. Kall det gjerne doktorsnillisme. Kanskje pasienten vil ha behandling ikke for å bli bra, men for å vise at man ikke kan bli bra. Sluttresultatet kan bli et plagsomt doktorterapifallittsyndrom.

\section{Får pasientuetterrettelighet konsekvenser?}

Pasientuetterrettelighet kan få konse-

kvenser, også for pasienten selv. Både forsikringsselskaper og NAV har det siste året inntatt en langt mer aktiv rolle dersom de mistenker svindel, bl.a. med videoopptak i det offentlige rom og nettsøk på enkeltindivider i Google. Dette har resultert i flere tilfeller av anmeldelser for svindel med etterfølgende rettssaker og krav om tilbakebetaling av utbetalte trygdemidler og forsikringer. Helsevesenet kan bidra til å forhindre disse individene i å gi seg i kast med et slikt løp, ved ikke ureflektert å igangsette langvarig symptomfikserende behandling med ditto sykmeldingsperiode, som kan vanskeliggjøre en normal tilfriskning og tilbakevending til arbeidslivet. Tidlig avdekking av pasientuetterrettelighet i symptompresentasjon og kliniske funn kan forhindre at behandlingen penses inn på et uheldig somatisk rettet behandlingsspor, som en dårlig erstatning for den psykososialt rettede behandlingen disse kan ha behov for.

\section{Bør det være noe som heter pasientplikter?}

Kanskje bør det finnes pasientplikter, særlig ved langvarige pasientforløp. Så lenge man oppsøker det offentlige helsevesen som bekoster det meste av utredning og behandling, bør man ikke bare ha rettigheter, men også visse plikter: plikt til å være sannferdig i sin fremstilling og plikt til å samarbeide etter beste evne. Bekjentgjørelsen av at det kan stilles visse krav også til pasienten og ikke bare til behandler, kan kanskje i seg selv få betydning i behandler-pasient-forholdet.

Men bare ordet pasientplikter - er det overhodet etisk salgbart som et diskusjonstema i de politiske miljøer i dagens VelferdsNorge? Eller innad blant de ulike behandlerkategoriene? Men hvis innføring av pasientplikter i noen grad kunne bidra til å redusere unødvendig bruk av helseressurser og antallet nye utbrente helsearbeidere og pasienttragedier, da var det kanskje verdt å belyse problemstillingen noe nærmere. En slik utredning måtte finne sted som et samarbeidsprosjekt mellom de helsefaglige, trygdemedisinske, juridiske og politiske miljøene.

\section{Håkon Lie}

haklie@online.no

Rygg- og nakkepoliklinikken

Aslakveien 14A, 0753 Oslo

\section{Oppgitte interessekonflikter: Ingen}

\section{Litteratur}

1. LOV 1999-07-02 nr. 63: Lov om pasientrettigheter (pasientrettighetsloven].

2. Grünfeld B. Kroniske muskelsmerter - noen sosialmedisinske perspektiv. Fibromyalgi. Oslo: Tano, 1995

3. Waddel G, McCulloch JA, Kummel E et al. Nonorganic physical signs in low back pain. Spine 1980; 5: 117-25.

4. Lie H. Aggravering av ryggsmerter. Tidsskr Nor Lægeforen 1990; 110: 3147-8.

5. Holtedahl R, Veierstad KB. Helse og funksjon etter yrkesskade. Tidsskr Nor Legeforen 2010; 130 1458-62. 